\title{
SYMBolic COMMUNiCATION AS SPEECH IN UNITED STATES SUPREME COURT JURISPRUDENCE
}

\author{
LUKASZ MACHAJ*
}

The Free Speech Clause of the United States Constitution is worldwide one of the most famous provisions of the American legal system. It constitutes a fundamental part of the First Amendment, stating clearly and unequivocally that 'Congress shall make no law [...] abridging the freedom of speech' (the rule also applies to state and local government by virtue of the so-called doctrine of incorporation). David A. Strauss remarks that 'the First Amendment to the US Constitution is the most celebrated text in all of American law'. With the possible exception of the Fifth Amendment dealing with judicial procedure, 'no other provision of the Constitution is so widely known to nonlawyers. Many nonlawyers even know some of the language of the First Amendment verbatim'. ${ }^{1}$ The significance of the clause is adequately underlined and emphasized by Cass R. Sunstein, who observes that 'more than anything else in the Constitution, the First Amendment's protection of free speech and free press symbolizes the American commitment to liberty under law. These [...] words have inspired and provoked not only Americans, but also reformers and constitution-makers all over the world'. ${ }^{2}$ The most important reason for the charm the provision exerts undoubtedly lies in its truly seductive explicitness. It does, however, need to be pointed out at the very beginning of the article that the simplicity mentioned is very much deceptive. In fact, 'rarely has such an apparently simple legal text produced so many problems of interpretation'. ${ }^{3}$ This is mostly due to the fact that the free speech provision is applicable to so many various 'pockets of conflict' ${ }^{4}$ which require differentiated legal perspectives that any search for simple and clear-cut rules must prove futile. For instance, analysis of the First Amendment needs to be undertaken in cases

DOI: $10.2478 /$ wrlae-2013-0039

* PhD; LLM; Department of Political and Legal Doctrines, University of Wroclaw.

1.machaj@prawo.uni.wroc.pl

1 David A Strauss, 'Freedom of Speech and the Common-Law Constitution' in Lee C Bollinger and Geoffrey R Stone (eds), Eternally Vigilant: Free Speech in the Modern Era (The University of Chicago Press 2002) 33.

2 Cass R Sunstein, Democracy and the Problem of Free Speech (The Free Press 1995) XI.

${ }^{3}$ Eric Barendt, Freedom of Speech (Oxford University Press 2007 ) 48.

${ }^{4}$ Rodney A Smolla, Free Speech in an Open Society (Alfred A. Knopf 1992) 18-19. 
concerning sit-ins, loudspeakers, satellites, magazine advertisements, billboards, flag desecration, nativity scene displays, incitement, advocacy of revolution, hecklers, profanity, obscenity, cable TV, computer networks, copyright, invasion of privacy, infliction of emotional distress, libel, student rights and many other issues. Such a wide range of problems cannot be resolved as was the Gordian knot, with one simple thrust of the sword. While Americans certainly hold freedom of speech in very high esteem, the relevant portion of the First Amendment cannot be understood as an absolute prohibition of any restraints (be it prior restraints or criminalization) imposed upon speech. In other words, the provision needs to be subjected to the thorough process of interpretation. This interpretive function - determining precisely what government may and may not do in the realm of speech - is performed by the US Supreme Court in the course of judicial review of legislation.

Even such a brief - by necessity - introduction makes it clear that the Free Speech Clause - as remains the case with almost every legal rule cannot be construed solely by using the tools of linguistic analysis. An interpreter has to take into account factors both systemic (its relationship with other regulations) and teleological (the First Amendment is supposed to facilitate search for truth, to protect individual autonomy and selffulfillment, to permit the principles of democracy and self-government to prosper, to embody the tenets of tolerance ${ }^{5}$ ). On the one hand, this leads to a narrowing of the scope of speech protected or even covered by the First Amendment in comparison with the literal meaning of the provision. This is quite a reasonable assumption since hardly anyone would be willing to extend free speech guarantees to true threats, libelous statements, incitement to crime, child pornography etc. These types of expression are categorically excluded from the reach of the First Amendment. On the other hand, the absurdity of a solely linguistic interpretation of the clause is clearly to be observed when we consider the case of ideas, emotions, opinions or beliefs conveyed through nonverbal means. Many such forms of expression are entirely analogous to oral and written speech in the sense that they too constitute communication 'through conduct limited in form to that necessary to convey the idea'. ${ }^{6}$ Silent movies, performance art, paintings, sculptures, computer games, pantomimes etc. - all appear to fit this criterion. The position that the First Amendment permits censorship of, say, musical productions seems axiologically untenable in light of the values the Free Speech Clause is intended to serve. Therefore, these types of communication, together with oral and written speech, should be conceptualized as so-called 'pure speech', which enjoys the highest level of constitutional protection in the United States legal system. The Supreme Court also seems to support this contention, though usually in implicit terms.

The case of symbolic speech is far more complicated. I am using this phrase in a sense proposed by Melville B. Nimmer, who defined it as 'communicative nonverbal conduct' (obviously one transcending the boundaries of 'pure speech'), distinguishing it from so-called 'speech plus'

\footnotetext{
${ }^{5}$ Wojciech Sadurski, Freedom of Speech and Its Limits (Kluwer Academic Publishers 2001) 8-35.

${ }^{6}$ Merriam-Webster's Dictionary of Law (Merriam-Webster's 1996) 398.
} 
(which is a 'verbal locution expressed within the context of conduct which in itself may not be regarded as communicative', e.g. marching or picketing with signs). ${ }^{7}$ The decision on whether to extend free speech guarantees to this type of expressive activity is not by any means simple. On the one hand, similarities between at least some instances of 'symbolic speech' and 'pure speech are too obvious to ignore'. As Louis Henkin explains:

There is nothing intrinsically sacred about wagging the tongue or wielding a pen: there is nothing intrinsically more sacred about words than other symbols. Other kinds of communication are also effective - [...] saluting a flag, kneeling in worship, holding a beloved hand. Even singular, idiosyncratic forms of expression can prove no less articulate, as when Simeon spent his days sitting on a pillar in the desert or the King of Denmark wore a six-pointed star. The Constitution protects "freedom of speech", which commonly connotes words orally communicated. But it would be surprising if those who poured tea into the sea and who refused to buy stamps did not recognize that ideas are communicated, disagreements expressed, protests made other than by word. ${ }^{8}$

Phenomenological analysis also justifies the position that there exists significant resemblance between 'pure' and 'symbolic' speech. In the opinion of Nimmer:

In one sense all speech is symbolic. At the moment the reader is observing black markings on paper which curl and point in various directions. We call such markings letters, and in groups they are referred to as words. What is being said in this sentence is meaningful only because the reader recognizes these markings as symbols for particular ideas. The same is true of oral speech which is simply the use of symbolic sounds. Outside of the science fiction realm of mind-to mind telepathic communication, all communications necessarily involve the use of symbols [...] All expression necessarily requires the use of symbols. ${ }^{9}$

Two other arguments for treating 'pure' and 'symbolic' speech in an equivalent manner also deserve to be mentioned. First of all, it is worth pointing out that - from a strictly functional and pragmatic standpoint both phenomena seem to operate analogously. Paul Berckmans remarks that 'the speech-like character of nonverbal behavior lies in the role it plays in social interactions. Instances of expressive conduct are like utterances [...] because like utterances they bring about particular responses in the participants in the process'. ${ }^{10}$ It can therefore be inferred that nonverbal activity may constitute - much like speech itself - a part of interpersonal and social communication. Contemporary understanding of the phenomenon of communication seems to support this conclusion. As W. Barnett Pearce points out, to adopt a communication perspective is to adopt a way of thinking about things which does not refer only to few select activities like 'speaking, writing, television, and film'. While these practices have traditionally been conceptualized as communicative, they remain in fact 'no more and no less fit subjects for communication analysis than any other kind of human activity'. Pearce concludes that any aspect of human behavior 'can be looked at as a process of communication in which

\footnotetext{
${ }^{7}$ Melville B Nimmer, 'The Meaning of Symbolic Speech Under the First Amendment' (1973) 21 UCLA Law Review 32-33.

${ }^{8}$ Louis Henkin, 'Foreword: On Drawing Lines' (1968) 82 Harvard Law Review 79.

${ }^{9}$ Nimmer (n 7) 33.

${ }^{10}$ Paul Berckmans, 'The Semantics of Symbolic Speech' (1997) 16 Law and Philosophy 152.
} 
resources are expressed and (re)constructed in practices'. ${ }^{11}$ Other definitions of communication also perceive it as a multi-modal occurrence which can consist of verbal and nonverbal components. ${ }^{12}$ For example, according to Robert Norton and Richard Brenders, the communication process takes place when 'selected information triggers an enthymematic response characterized by nonrandom connections' in a recipient which correspond to and are coordinated with connections of a sender. ${ }^{13}$ Wendy Leeds-Hurwitz emphasizes - in a similar vein - that communication involves the use of certain signs (symbols) and the combination of symbols into codes, which in turn allows us to 'socially construct (produce, maintain, repair, transform) reality', enabling human interaction. ${ }^{14}$ Finally, the words of Ralph V. Exline and B. J. Fehr (1978: 121) deserve to be mentioned:

All behavior is potentially communicative. Any given behavior becomes communicative when it produces a change in a receiver. This change may range from the level of the neuron to the level of more overt behavior. In essence, the change is the reaction of the receiver to the communicative event. From this point of view, all aspects of a person's behavior may be part of the message one sends. ${ }^{15}$

The aspect common to all of the definitions mentioned is their either express or at the very least implicit assumption that communication does not embrace verbal activities exclusively. If we consider the First Amendment as an instrument designed to ensure maximally unfettered communication, the extension of its protection to 'symbolic speech' quite naturally follows.

The last argument for making the Free Speech Clause applicable to some nonverbal activities is of a purely teleological nature. Protection of 'symbolic speech' can serve exactly the same interests as protection of verbal utterances; expressive activities are often - from an axiological standpoint - indistinguishable from 'pure speech'. ${ }^{16}$ Making the First Amendment relevant to nonverbal communication certainly enlarges spheres of personal autonomy and individual self-fulfillment, widens the range of possibilities for participation in a democratic process, adds yet another dimension to principles of self-government and implements the rule of tolerance. While it may not contribute to a discovery of truth in an Aristotelian sense ('symbolic speech' is usually more of an emotional and expressive nature than a descriptive), it still can enhance our knowledge of moral, political and social reality. Finally, it also enriches the free exchange of ideas. It is entirely plausible that rigorous exclusion of nonverbal communication from the reach of the First Amendment would significantly

\footnotetext{
11 W Barnett Pearce, Communication and the Human Condition (Southern Illinois University Press 1989) 25.

12 Beth Haslett, Communication: Strategic Action in Context (Lawrence Erlbaum Associates 1987) 4-5.

13 Robert Horton, Richard Brenders, Communication and Consequences: Laws of Interaction (Lawrence Erlbaum Associates 1996) 17-18.

14 Wendy Leeds-Hurwitz, Semiotics and Communication: Signs, Codes, Cultures (Lawrence Erlbaum Associates 1993) 15.

${ }^{15}$ Ralph V Exline, B J Fehr, 'Applications of Semiosis to the Study of Visual Interactions' in Aron W Siegman \& Stanley Feldstein (eds), Nonverbal Behavior and Communication (Lawrence Erlbaum Associates 1978) 121.

${ }^{16}$ Edwin C Baker, Human Liberty and Freedom of Speech (Oxford University Press 1989) 79 .
} 
reduce the presence of certain viewpoints - particularly those embraced by minorities - in public debate. Fierce anti-war protest, radical opposition to specific governments, contempt for national tradition - 'symbolic speech' seems to be a medium uniquely suited to expression of such sentiments. In such cases verbal locution very often cannot serve as a sufficiently equivalent vehicle.

The preliminary refusal to banish symbolic speech beyond the boundaries of coverage by the Free Speech Clause is only the first step on a very long road to determining the level of First Amendment protection to which people who engage in expressive activity are entitled. The next fundamental problem relates to the possible criteria which should be employed in order to distinguish between communicative and noncommunicative nonverbal behaviour. The need for such a demarcating line is self-evident since, as Franklyn S. Haiman explains:

Everything that one does, every action that one takes or fails to take, "speaks" to anyone who is interested in looking for the message. That is not to suggest that all behavior consciously communicates, is intended as communication, or is perceived by others as sending a message. But once we accept the fact that all behavior is capable of being understood as communication, we will have a better appreciation of the complexities we face in distinguishing among various behaviors for First Amendment purposes. ${ }^{17}$

A similar statement, if slightly stronger, is delivered by Raymond Gozzi, Jr.:

When two human beings enter each other's field of perception, they are then in communication. There is no sender or receiver. Each person is both "sending" and "receiving," constantly. They cannot not communicate. This means that if people can see each other, or hear each other, or touch each other, they are in communication. ${ }^{18}$

The conclusions emerging from these quotes are unequivocal: precisely every voluntary human action can be treated as an expression - conscious or subconscious, intentional or unintentional - of the feelings, emotions, convictions, ideas, beliefs or passions of the individual. In other words, human behaviour is immanently communicative. When we smile, we may express satisfaction, sarcasm, irony, pity, malice, enthusiasm, waywardness, contempt etc. Wearing an eccentric hairstyle may express dislike for social conventions, a wish to fit seamlessly into a peer group, a desire to make oneself visible, a feeling of generational rebellion etc. A terrorist strike may be a manifestation of political doctrine, of a certain psychological disposition, of hatred towards a specific civilization or way of life etc. A soldier committing suicide while incarcerated in order to avoid passing valuable information to the enemy under torture may express in this manner his staunch allegiance to his government, his loyalty for his brothers-inarms, his belief that honour and duty are more important than individual existence, his fear of pain etc. Even entirely unthinking and reflexive actions - eating an omelette, making a cup of tea, walking from point $\mathrm{A}$ to point $\mathrm{B}$, sitting on a couch - are communicative for at the very least they express the subjective opinion of the actor that undertaking them lies in his interests.

${ }^{17}$ Franklyn S Haiman, Speech and Law in a Free Society (The University of Chicago Press 1981) 31.

18 Raymond Gozzi, Jr., ‘A Shared Field Model of Communication' (2004) 61 ETC.: A Review of General Semantics 396. 
The recognition of communication as an omnipresent phenomenon should patently not lead to a limitless extension of the First Amendment guarantees. Adopting such a stance would be utterly irrational from a pragmatic standpoint (literally every legal rule would have to be subject to the Free Speech Clause scrutiny) and - paradoxically - very dangerous with respect to axiology (the actual level of constitutional protection of speech would have to be drastically diminished). We need therefore to introduce further criteria. The first possibility is attempting to categorize and classify different types of nonverbal activity and granting the First Amendment safeguards only to some of them. In short, we would have to lead an introductory investigation into the particulars of a given behaviour in order to determine whether it deserves to be treated as speech in a constitutional sense. Let us present a few of the most representative and viable ideas concerning this demarcating line (bearing in mind that they do not need to be regarded as mutually exclusive). The First Amendment sphere of relevance may for example be narrowed to solely those instances of symbolic speech which deal with a defined and particular subject matter, e.g. only to political nonverbal expression. ${ }^{19}$ The second concept would involve applying constitutional guarantees only to that nonverbal activity which is relatively particularized, concretized and at least potentially understandable as communicative by viewers, audience or recipients (bearing in mind an inherent imprecision of symbolic speech in comparison to verbal locution). An inquiry might also focus primarily on teleological matters by analyzing the conscious intent of a speaker/actor who is supposed to be willing to express ideas or emotions. ${ }^{20}$ Yet another alternative would be limiting the First Amendment protections only to nonverbal expression which is nonviolent and noncoercive, which does not invade a sphere of the autonomy of other people and which is substantively (i.e. not just instrumentally) valued by a speaker/actor. ${ }^{21}$ The fifth option would be attempting to determine which of the component parts of the activity analyzed plays a predominant role and confining First Amendment applicability only to those instances of behaviour where the element of expression is more important than the non-expressive ingredient (it is rather obvious that assassination or homicide will not fulfill this criterion). ${ }^{22}$ Each of the types of inquiry mentioned above may also be complemented by the requirement that a careful and in-depth contextual examination of the surrounding circumstances is conducted in order to determine the constitutional status of the given nonverbal activity. ${ }^{23}$ Making use of such criteria should supposedly enable us to define every nonverbal activity as either speech (or rather "symbolic speech" or "expressive activity") or action (conduct) unprotected by the First Amendment. This separation - if successful - possesses a dichotomous character: the Free Speech Clause is either applicable or totally non-applicable to a given behaviour.

\footnotetext{
${ }^{19}$ Frank A Morrow, 'Speech, Expression, and the Constitution' (1975) 85 Ethics 236-242.

${ }^{20}$ Frederick Schauer, 'Freedom of Expression Adjudication in Europe and in the United States: a Case Study in Comparative Constitutional Architecture' in Georg Nolte (ed) Europe and US Constitutionalism (Cambridge University Press 2006) 60-61.

${ }^{21}$ Edwin C Baker, 'Scope of the First Amendment Freedom of Speech' (1978) 25 UCLA Law Review 990, 1009-1029.

22 Thomas I Emerson, The System of Freedom of Expression (Random House 1970) 79-81.

${ }^{23}$ Berckmans (n 10) 176.
} 
The United States Supreme Court has in general accepted the necessity of introducing a mechanism for such preliminary analysis. In 1968 the Justices agreed in no uncertain terms that that they "cannot accept the view that an apparently limitless variety of conduct can be labeled "speech" whenever the person engaging in the conduct intends thereby to express an idea' ${ }^{24}$ The Supreme Court has therefore rejected the position that speech occurs every time the subjective intent of an actor is to communicate something. This seems to be an eminently reasonable attitude. However, it was not until 1974, when one of the flag desecration cases was decided, that the Court finally attempted to establish positive criteria for determining whether a given conduct is sufficiently imbued with communicative elements to deserve First Amendment protection. The majority of Justices devised two lines of inquiry, which of course must be followed simultaneously. The first question is whether an alleged speaker intended to convey a particularized message; the second question is whether 'in the surrounding circumstances the likelihood was great that the message would be understood by those who viewed it'. ${ }^{25}$ This standard came to be known as the 'Spence test'. It is important to note that the Court has not expressly applied the test in every subsequent case. This apparent lack of consistency is easily explained. The test is - by necessity, in my view - quite vague and equivocal. It does not provide us with a clear-cut answer to every relevant legal dilemma; its application must perforce be capricious and arbitrary, stimulating judicial activism and provoking judicial lawmaking. I believe that for these reasons the Court has implicitly instituted a presumption of expressiveness and has been willing - in doubtful cases - to assume that the behavior in question is in fact sufficiently communicative to be covered by the Free Speech Clause. In short, the Spence test serves only to deny speech status to such actions as are patently not entitled to enjoy it (usually in such cases the Court refuses even to grant certiorari and hold a hearing).

The applicability of the Spence test is therefore rather narrow. The Supreme Court still required legal instrumentation in order to reduce a potentially gargantuan extension of First Amendment relevancy. This is why the alternative approach to the issue had to be developed. Its basic premise was a moving of the focus away from a concentration on the properties of a particular conduct and more towards the analysis of legislation which allegedly abridges the freedom of symbolic expression. The logic of this approach is best elucidated by Nimmer. ${ }^{26}$ Every symbolic speech possesses communicative and non-communicative elements (though this does not mean that they can be separated); it is both action and expression. If a particular legislation is motivated by or aimed at the speech component of nonverbal activity (i.e. serves an anti-speech interest), it should be interpreted as an encroachment upon the First Amendment. In other words, symbolic expression is entitled in this case to enjoy exactly the same level of constitutional protection as verbal speech does. The rationale is simple: in both situations the governmental purpose is either to eliminate entirely the expression of ideas, thoughts, feelings, emotions etc. or at the very least to confine it; additionally, such a policy is often based upon

${ }^{24}$ The United States v O'Brien 391 US 367, 376 (1968).

${ }^{25}$ Spence v Washington 418 US 405, 410-411 (1974).

${ }^{26}$ Nimmer (n 7) passim. 
content or viewpoint discrimination, which is in general unacceptable under the Free Speech Clause. However, if a certain legal rule serves a non-speech interest (i.e. is motivated by or aimed at the action component or consequences of nonverbal activity), the level of constitutional protection allotted to symbolic expression should be very significantly reduced (the specific standards may clearly differ). An example given by Larry Alexander perfectly illustrates this point: convicting someone for creating a fire hazard by burning an American flag raises few constitutional doubts or none - whereas criminalizing flag burning in itself because it desecrates and undermines social values and national tradition clearly implicates the First Amendment, is constitutionally suspect and - at the very least - ought to be very carefully examined for admissibility. ${ }^{27}$ The United States Supreme Court saw the need to introduce such an inquiry. This has been embodied in the so-called O'Brien test. ${ }^{28}$ According to this standard, regulation of symbolic expression is valid from a First Amendment standpoint if it remains within the powers of the government as set by the Constitution; if it promotes a substantial governmental interest; if the governmental interest is unrelated to the suppression of free expression; and if the incidental restriction on First Amendment freedoms is no greater than is essential to the furtherance of that interest. An application of the O'Brien standard is not of course a simple, uncontroversial, syllogistic exercise. The four conditions of the test demand from judges an assessment and gradation of the governmental interests (always a tricky and subjective endeavour), the identification of the objective of the state in introducing particular legislation and an evaluation of its nature as far as freedom of speech is concerned, careful analysis of whether the legal rules in question do not prohibit or punish more speech than is necessary. The courts are left with much discretion in consideration of these issues, which can easily reach excessive proportions. Nevertheless, such an intermediate scrutiny of laws pertaining to symbolic speech as that embodied in the O'Brien test appears to be a reasonable compromise between an irrational and counterproductive unleashing of the full force of the Free Speech Clause and ignoring the First Amendment altogether.

Before I attempt a brief examination of specific Supreme Court decisions concerning symbolic speech, two additional reservations need to be mentioned. First, as I have already explained, the Free Speech Clause guarantees are not absolute. Apart from noted categorical exceptions, pure speech can also be restricted if the scrutinized legislation conforms to certain standards of judicial review. These tests have been developed by the Supreme Court over time and are currently legally binding. Further on, I will try to evaluate the analyzed legislation in the light of these standards even if they were enacted at a much later date. Even though it is undoubtedly an anachronistic exercise, it will certainly be useful and revealing. Two such tests are most important in the context of this article. The first is the so-called strict scrutiny analysis which declares that governmental restriction of speech is constitutionally acceptable if it is justified by a compelling governmental interest and is narrowly tailored to

${ }^{27}$ Larry Alexander, Is There a Right of Freedom of Expression? (Cambridge University Press 2005) 41-42.

${ }^{28}$ The United States $v$ O'Brien (n 24) 377. 
achieve that interest. ${ }^{29}$ This standard is very difficult to meet; the prevalent majority of laws subjected to it have been rendered constitutionally invalid. This test is used to legitimize a total prohibition of certain speech based on its content or even on viewpoints expounded by a speaker. The second is the so-called 'time, place, and manner' standard according to which a law restricting speech may pass constitutional muster if it may be justified without a reference to the content of the regulated speech (i.e. it does not discriminate upon the basis of content or upon the viewpoints expressed by the speaker), if it is narrowly tailored to serve a significant governmental interest and if it leaves open alternative channels for communication of the idea or information. ${ }^{30}$ This test is used to justify legislation which does not enact a total proscription of certain speech, but which places only a number of limits upon the time, place or manner of its formulation (like laws banning intrusive solicitation, excessive noise, visual clutter etc.). Since the consequences of such legislation are not as serious as in the situation previously discussed, this standard is relatively easy to meet. It goes without saying that both of these tests also apply to symbolic speech. The second point which needs to be made concerns required properties of legislation relevant to speech (and by extension to expressive conduct). Such law has to conform to several basic formal - non-sensitive in the light of content conditions. This means that it cannot be either overbroad (extend to a substantial amount of protected, as well as unprotected, activities) or vague (be such that a person of average intelligence is unable to ascertain conclusively whether the law is applicable to a particular conduct); all legislation exhibiting these defects will be invalidated. ${ }^{31}$

Let us now turn to a brief examination of the major United States Supreme Court decisions on specific examples of alleged symbolic speech.

1) Public display of a red flag as a sign of opposition to organized government

In 1929 19-year old Yetta Stromberg, communist youth camp counselor, was convicted for violating the so-called 'Red Flag Law' of California, which made a crime of - among other things - displaying any flag or banner in any public place as a sign, symbol or emblem of opposition to organized government, an invitation or stimulus to anarchistic action or an aid to propaganda of a seditious nature. In 1931 the Supreme Court invalidated the verdict because the law - as far as the 'sign of opposition to organized government' element was concerned - was wide open to challenge on overbreadth and vagueness. Though the decision was formally justified by the $14^{\text {th }}$ Amendment, which declares it impermissible for the States to deprive any person of life, liberty or property without due process of law, the Justices left hardly any doubt as to what component of individual liberty was infringed by the regulation. As Chief Justice Charles Evans Hughes pointed out in the majority opinion, the concept 'of liberty under the due process clause of the Fourteenth Amendment embraces the right of free speech'. ${ }^{32}$ Hughes also emphasized the necessity of maintaining the

\footnotetext{
${ }^{29}$ Steven L Emanuel, Constitutional Law (Emanuel Publishing Corp. 2000) 427.

${ }^{30}$ ibid 455.

${ }^{31}$ Geoffrey R Stone, Louis M Seidman, Cass R Sunstein, Mark V Tushnet, The First Amendment (Aspen Law \& Business 1999) 105-116.

${ }^{32}$ Stromberg $v$ People of State of California 283 US 368 (1931).
} 
'opportunity for free political discussion to the end that government may be responsive to the will of the people and that changes may be obtained by lawful means'. It can therefore be concluded that the Supreme Court considered the 'Red Flag Law' to implicate at least indirectly the First Amendment, admitting - per facta concludentia - that the Free Speech Clause is applicable to nonverbal expression. Therein lies the fundamental importance of the decision. Of course, judged by the standards of today, the striking down of the conviction cannot be seen as surprising. The behaviour exhibited by Stromberg is manifestly expressive under the Spence test; the 'Red Flag Law' - as a content-discriminatory regulation aimed at total suppression of certain speech - is subject to strict scrutiny and fails the 'narrow tailoring' requirement. Nevertheless, taking the realities of 1931 into account, the Stromberg decision was truly groundbreaking.

2) Refusal to salute an American flag

In 1942 three Jehovah's Witnesses decided to file a motion with the West Virginia Board of Education containing a request to release their children from participation in a patriotic ritual - obligatory under threat of expulsion - taking place in public schools. During these ceremonies schoolchildren were legally - on the basis of state statute - obliged to salute an American flag (in addition to other duties, such as recitation of the Pledge of Allegiance). The Board refused to accept the motion and some time later the case ended up before the Supreme Court. The majority of Justices - in a decision founded on First Amendment principles - ordered the state to carve out an exception in the statute for Jehovah's Witnesses since any participation in such rituals violated fundamental tenets of their religion. Today the decision hardly seems controversial. In light of current standards, the West Virginia law, for obvious reasons, would be subjected to strict scrutiny with a predictably negative result. However, the decision should be seen as one of the milestones on the road to contemporary Supreme Court jurisprudence on the First Amendment. Apart from contending that to compel expression is to abridge freedom of speech, the Justices for the first time unequivocally endorsed a concept of symbolic speech. In the famous and powerful words of Justice Robert H. Jackson:

The flag salute is a form of utterance. Symbolism is a primitive but effective way of communicating ideas. The use of an emblem or flag to symbolize some system, idea, institution, or personality, is a short cut from mind to mind. Causes and nations, political parties, lodges and ecclesiastical groups seek to knit the loyalty of their followings to a flag or banner, a color or design. The State announces rank, function, and authority through crowns and maces, uniforms and black robes; the church speaks through the Cross, the Crucifix, the altar and shrine, and clerical raiment. Symbols of State often convey political ideas just as religious symbols come to convey theological ones. Associated with many of these symbols are appropriate gestures of acceptance or respect: a salute, a bowed or bared head, a bended knee. A person gets from a symbol the meaning he puts into it, and what is one man's comfort and inspiration is another's jest and scorn. ${ }^{33}$

It should also be pointed out that the decision attributed expressive properties to being silent. In some circumstances lack of activity ought therefore to be treated as symbolic speech.

3) Draft card burning

${ }^{33}$ Barnette v West Virginia Board of Education 319 US 624, 632-633 (1943). 
On 31 March 1966 David O'Brien publicly burned his military draft card in order to demonstrate his opposition to the Vietnam War. He was convicted for violating federal statute which prohibited 'wilful and knowing mutilation' of Selective Service registration certificate. This law had been introduced for the purpose - judging by speeches made on the floor of the United States Congress - of preventing this very method of conveying antiwar beliefs which had begun to gain in popularity. Put simply, O'Brien decided to communicate his convictions by virtue of illegal action. The case reached the Supreme Court in 1968; Chief Justice Earl Warren wrote the majority opinion. ${ }^{34}$ After some initial hesitations, Warren agreed to assume that O'Brien's conduct was expressive enough to bring the First Amendment into the fray, though he did it with evident reservations and without a comprehensive justification. The Spence standard - which was established six years later - confirms the intuition of the Justice for the criteria of communicative intent and understandability to viewers were clearly met by the action of the accused. The rest of the opinion was devoted to the establishment of the O'Brien standard and to its application to the specific circumstances of the case. Warren concluded that the relevant legislation was valid under the newly devised test both on its face and as applied. The Court asserted that in general the statute in question concerns behaviour, only incidentally burdening speech. In the most debatable fragment of opinion, Warren stated that the interest served by the law is strictly of a non-expressive nature. Ignoring the speeches made on the floor of the legislature, the Chief Justice contended that the real objective of the statute is ensuring a smooth functioning of the draft system, in which registration certificates perform an important role. By selecting this interpretive avenue, the Supreme Court chose a particular method of verifying whether the third condition of the O'Brien test is met: instead of focusing on the subjective intent of legislators, it decided to analyze the interests served by legislation in abstracto. If a non-expressive purpose for the creation of a legal rule can be found, such a law can be rationalized under the First Amendment even if the advancement of this interest was furthest from the minds of the legislators. The adoption of such a stance weakened a protective strength of the O'Brien standard very significantly. After clearing this hurdle, Warren found the remaining part of the test easy to pass. Introduction of the relevant legislation undoubtedly remained within the powers of the federal legislature; the law promoted the smooth functioning of the draft mechanism, which can be described as a substantial governmental interest; the statute did not burden free expression excessively. O'Brien's conviction was upheld.

4) Wearing a black armband in political protest

In December 1965 three teen public school students were suspended for wearing black armbands in order to protest governmental policy in Vietnam. Reviewing the constitutionality of this sanction, the Supreme Court contended that the conduct of the pupils was "closely akin to "pure speech"" 35 and therefore entitled to comprehensive First Amendment protection (the Spence test supports this conclusion). Since neither teachers

\footnotetext{
34 The United States $v$ O'Brien (n 24).

${ }^{35}$ Tinker $v$ Des Moines School District 393 US 503, 506 (1969).
} 
nor students 'shed their constitutional rights to freedom of speech or expression at the schoolhouse gate ${ }^{36}$ and since the conduct in question was not disruptive or interfering with classroom discipline, the reaction of the school - in the view of the Court - had violated the Free Speech Clause. The Justices remarked that 'the action of the school authorities appears to have been based upon an urgent wish to avoid the controversy which might result from the expression, even by the silent symbol of armbands, of opposition to this Nation's part in the conflagration in Vietnam'. ${ }^{37}$ Had the behaviour of the pupils resulted in some disturbance or disorder, the suspension might have been justified. In other words (and using contemporary doctrine), such a disciplinary action is permitted only as a concretization of either 'time, place and manner' or 'incidental restriction' regulation (government interest in each case being the maintenance of order, calm, discipline and a proper learning environment in public schools).

5) Flag desecration

Following a series of decisions stretching from 1969 to $1990,{ }^{38}$ the Supreme Court has concluded that in some cases desecration of an American flag (and flag burning in particular) constitutes symbolic speech which conveys the strong political convictions of the actor and is entitled to First Amendment protection. Application of laws prohibiting flag profanation to expressive conduct - as a regulation aimed at the content of expression - is subject to strict scrutiny. While the fostering of national unity and protection of the special place of the flag in American life may conceivably be defined as 'compelling governmental interests', the use of criminal sanctions in promoting these objectives fails the prong of 'narrow tailoring'.

6) Financial contributions to political parties and campaigns

The Supreme Court has not identified such conduct as an example of symbolic speech. ${ }^{39}$ In my opinion, such a position is mistaken in that a monetary donation to a party or a candidate is - at least sometimes intended to convey a particularized message of political support which is quite easily understood by observers. The Spence test is therefore passed. It has to be admitted that defining the analysed behaviour as expressive action would in all probability result in the invalidation of legislation regulating financial aspects of the political process (such laws would fail the strict scrutiny standard which would be applicable in these circumstances). I believe that this political consideration has influenced the stand of the Court.

7) Sleeping in a park

In 1984 the Supreme Court agreed to assume that sleeping in a national park during a political demonstration for the purpose of dramatizing the plight of homeless people has enough expressive qualities to merit some First Amendment protection. The rule prohibiting this

\footnotetext{
36 ibid.

37 ibid 510.

${ }^{38}$ Street $v$ New York 394 US 576 (1969); Smith v Goguen 415 US 566 (1974); Spence v Washington (n 25); Texas v Johnson, 491 US 397 (1989); The United States v Eichman 496 US 310 (1990).

${ }^{39}$ See for example Buckley $v$ Valeo, 424 US 1 (1976).
} 
conduct may, however, be justified as valid under 'time, place and manner' standard. ${ }^{40}$

8) Cross-burning

In two decisions ${ }^{41}$ the Supreme Court contended that cross-burning as a form in which racist prejudices are manifested - is an expressive activity. The scope of constitutional guarantees allotted to this conduct depends on contextual factors and is analogous to safeguards given to equivalent verbal locution. If cross-burning is directed at a specific person, constituting a true threat, intimidation or 'fighting word' (a word which by its very utterance tends to incite an immediate breach of peace), it fits precisely into one of the categorical exceptions from First Amendment protection and may be criminalized; if it is just a generalized expression of political sentiments (conveyed, say, during a Ku-Klux-Klan rally), it remains protected by the Free Speech Clause in the same manner as verbal hate speech.

9) Nude dancing

In a series of decisions ${ }^{42}$ the Supreme Court declared nude dancing as a form of adult entertainment - to be symbolic speech (though I believe that such activity should be treated as an artistic expression on a par with other theatrical performances, at least as long as there is no physical contact between performer and viewer). Nevertheless, the Court stated that 1) zoning regulations requiring spatial dispersal or concentration of nude dancing establishments may be justified under the 'time, place and manner' standard, and 2) absolute prohibition of 'totally nude' dancing may be justified under the O'Brien test. In both situations the non-expressive interest of government is elimination of secondary effects of such expression, such as deterioration of neighbourhoods, reduction in real estate values, increased criminal activity etc. Nude dancing may also be totally restricted if it falls under the definition of obscenity (in the same way 'pure speech' may be).

In my opinion, the American judicial doctrine of symbolic speech may teach us one important lesson. If communication is a multi-modal phenomenon which often takes on a form of nonverbal expressive activity, we sometimes must, while analyzing legislation ostensibly pertaining to conduct, take free speech interests into account. I believe that this necessity is often overlooked in European legal systems. How many lawmakers or judges would think to consider seriously the free speech implications of cases involving, say, a student refusing to sing a national anthem, a protester burning official documents or a dancer performing a strip-tease? I am not contending - and neither does the Supreme Court - that freedom of speech should always be a trump card during a settlement of such legal disputes, particularly since - allowing for a little generalization - European systems attach far lesser importance to their respective constitutional Free Speech Clauses than the US Supreme Court does to the First Amendment. Nevertheless, this dimension should never be completely ignored. Free and unfettered communication is far too precious a value to let that happen.

${ }^{40}$ Clark v Community for Creative Non-Violence, 468 US 268 (1984).

${ }^{41}$ R.A.V. v City of St. Paul, 505 US 377 (1992); Virginia v Black, 538 US 343 (2003).

${ }^{42}$ Schad v Borough of Mount Ephraim, 452 US 61 (1981); Barnes v Glen Theatre, Inc., 501

US 560 (1991); City of Erie v Pap's A. M., 529 US 277 (2000). 